\title{
Moringa oleifera: Potential areas of cultivation on the Iberian Peninsula
}

\author{
M. Godinoa, C. Arias, M.I. Izquierdo \\ Department of Forest Engineering, Technical University of Madrid (UPM), E.U.I.T. Forestal, Ciudad Universitaria \\ s/n, 28040 Madrid, Spain.
}

\begin{abstract}
Moringa oleifera is a tree native to the southeast of the Himalaya that, by its characteristics, spread through southern Asia. Although the species is considered of tropical climate, its presence as native in Indian Kashmir, between 1,200 and 1,800 meters of altitude, is an indication that the tree could have a greater climatic range. Today, Moringa oleifera is a panecuatorial species, has widely spread throughout America, from the southern part of the US to northern Chile and Argentina. In Spain, moringa is beginning to grow in the subtropical zone of the peninsula and the Canary and Balearic Islands.

Its multiple uses make moringa an attractive crop in different fields of food, human or animal, also in cosmetics, biofuels and pharmaceuticals.

The aim of this study is to determine possible areas of cultivation on the Iberian Peninsula. For that reason we have compiled information about the climatic requirements of the species for its suitable development; we have validated this data with that provided by the AEMET "Iberian Climate Atlas", using ArcGis v. 10; and we have placed this information on a map.
\end{abstract}

Keywords: Moringa oleifera, bioclimate, frost, agroclimatic conditions

\section{INTRODUCTION}

Moringa oleifera is a tree which belongs to the monogeneric family Moringaceae, with thirteen species distributed throughout Africa, Madagascar and India.

Known since ancient times for its nutritional and medicinal properties and its oil, Moringa oleifera was distributed since ancient times from India to Africa and to Southeast Asia and the Philippines. With the arrival of the Spaniards in the Philippines, and the exchange of plants by the Nao de Manila (Pacheco, 2006), moringa was introduced into America and Europe. There is evidence that in the eighteenth century M. oleifera was brought to the Iberian Peninsula, as quoted in the List of Plants of the Royal Botanical Garden of Madrid 1796 (Gomez Ortega, 1796). Today, moringa is cultivated and growing naturally in at least seventy countries of tropical and subtropical regions of the world, mostly in underdeveloped regions.

Cultivation of moringa is spreading and its possible introduction into new biogeographic regions is being studied. For example, in Europe, it is being introduced in the Mediterranean biogeographic regions, in the south of the Iberian Peninsula and the Balearic Islands, and Macaronesian, in the Canary Islands. This paper focuses on the Spanish part of the western Mediterranean region.

All parts of the plant are used in some way. Its stems, flowers, fruits and seeds are edible and have high percentages of protein, vitamins and minerals. It is used as food for both people and animals (mammals, birds and fish) and as a nutritional supplement.

a E-mail: miguel.godino@upm.es 
The seed of M. oleifera contains 35\% of high quality oil, with a content of oleic acid similar to olive oil. In addition, the "cake" obtained after pressing the seeds is used in depuration and water purification thanks to the natural flocculent power of their seeds; this is an effective and inexpensive method (Jahn et al., 1986; Sutherland et al., 1989); it is also used as fertilizer and animal feed. When feeding mammals, moringa generates significant yield increases in both weight gain and milk production (Sánchez, 2004).

Its low density wood is used as firewood and to make charcoal; the pulp may be used for paper and for bioethanol

Moringa oleifera is an oleaginous tree of a very fast growth. In the first year of life, moringa may exceed four meters in height (Prabhakar, 2008); and it can easily regrow . It spreads easily, also by seed and by vegetative material. If the tree is derived from seed, it may live or 20 years; but if it comes from cutting, the average age is only 10-15 years. When cultivated at very high densities, the life span is only four or five years before it is replanted. In India annual varieties have been obtained that allow its cultivation in temperate climates (Falasca and Barnabas, 2008).

M. oleifera is considered a species of light. Lack of light can cause losses of $30 \%$ of young seedlings (Sánchez et al., 2006). In Sudan, Jahn (1986) made a study providing data on germination and more favorable growth under half shade conditions, with $86 \%$ of seed germination and $20 \mathrm{~cm}$ size of suckers at 75 days after planting, compared to $78 \%$ of germination at full light and $11 \mathrm{~cm}$ of growth of suckers during the same period.

M. oleifera grows and develops well in tropical and subtropical climates. In its area of origin, and where it has been introduced, the plant grows in areas where the average temperature is between 12.6 and $40{ }^{\circ} \mathrm{C}$, withstanding high temperatures till $48{ }^{\circ} \mathrm{C}$ (Roloff, 2009). Regarding its cold hardiness, $\mathrm{M}$. oleifera grows in the USDA hardiness zones: $9 \mathrm{~b}$ to 12 , it resists light frosts down to $-3{ }^{\circ} \mathrm{C}$, but is seriously affected when temperatures drop below $-5{ }^{\circ} \mathrm{C}$, even for one night (Bertoni, 1927; NRC, 2006). In Spain, Sanchez LorenzoCáceres (2004) considers that its cultivation as an ornamental plant could be in the hardiness zone 11 (Tmin of $4-10{ }^{\circ} \mathrm{C}$ ), which means that moringa could be introduced for other purposes than shown, in the subtropical zone of the Iberian Peninsula and in places with light frosts.

According to Köppen-Geiger climate classification, the southwestern region of the Himalayas, where Moringa oleifera is native, has the following climates: hot steppe (BSh), subtropical hot-summer (Cfa), dry-summer subtropical (Csa) and subtropical-dry winter (Cwa)_(OCHA, 2015). Except for the latter, the first three are found on the Iberian Peninsula. In the region of Kashmir, the plant is found between 1,200 and 1,800 meters elevation (Khuroo, 2011), the same height as in Oaxaca (Mexico) (Jahn, 1986) making it possible to find seed varieties that are suited to the climates of the Iberian Peninsula.

In its habitat, the average annual temperatures have large fluctuations. According to the literature, during the coldest months, moringa resists few and light frosts, between $-1^{\circ} \mathrm{C}$ and $-3{ }^{\circ} \mathrm{C}$; while during the warmest months, it resists $38^{\circ} \mathrm{C}$ to $48{ }^{\circ} \mathrm{C}$. However, its optimum growth is between 25 and $35^{\circ} \mathrm{C}$. According to Radovich (2011), the average annual minimum temperature, which the plant tolerates is $15^{\circ} \mathrm{C}$.

According to Muhl et al. (2011), temperature is the key factor that influences the growth and productivity of $M$. oleifera. These authors conducted several studies of the plant and proved that the growth is favored by increasing temperatures and that the plant can adapt to lower temperatures. This can be important for establishing plantations in colder climates. In these colder climates there is the possibility of cultivating moringa in greenhouses.

M. oleifera cultivation can start when night temperature exceeds $15{ }^{\circ} \mathrm{C}$ (Prabhaka, 2008). If the average temperature is below $14^{\circ} \mathrm{C}$, moringa cannot bloom or germinate, and can only be reproduced by vegetative material (Garcia Roa, 2003). With daily average temperatures below $20^{\circ} \mathrm{C}$ the plant does not grow (Radovich, 2011).

The annual rainfall in the region of origin of M. oleifera ranges from 500 up to 2,200 $\mathrm{mm}$ (Roloff, 2006), while in arid and semiarid areas of Arabia and Ethiopia where it also grows, rainfall can be down to $300 \mathrm{~mm}$. The moringa tree is resistant to drought; in areas 
with subtropical climate $M$. oleifera can tolerate up to six months of dry season if the annual rainfall reaches $500 \mathrm{~mm}$. It can be planted in areas where rainfall varies from $500-1,500 \mathrm{~mm}$ (Parrotta, 2000). When cultivated for fodder production, it needs at least $800 \mathrm{~mm}$ of precipitation (Broin, 2010).

\section{Objective of the study}

The aim of the present work is to define the areas bioclimatically suitable for $M$. oleifera cultivation on the Iberian Peninsula and the Balearic Islands, either as a forage crop or for production of pods and seeds.

Like with other crops, moringa dissemination and cultivation is determined by the vital requirements of the plant and by climatic boundaries of the region where one wants to cultivate it.

\section{MATERIALS AND METHODS}

To carry out this study we used the application ArcMap and ArcCatalog from ARCGIS 10 software. The first application is oriented to building application maps, edit geographic information layers and to analyze spatial data; and the second one manages the files that store the geographic data.

The data that have been used are: maps of annual and monthly mean temperatures, maps of maximum average temperatures, monthly and annual, maps of monthly and annual mean minimum temperature, and maps of number of days of frost. All data, in digital format (.TIFF), were used to prepare the "Iberian Climate Atlas" (2011), based on the results of climatological normals from the period 1971-2000. These data were provided by the Spanish State Meteorological Agency (AEMET, 2011).

From the recompilation of available information regarding the moringa distribution range, both under natural and cultivated conditions, the following limiting factors were obtained:

- Moringa oleifera does not survive at temperatures above $48^{\circ} \mathrm{C}$;

- Moringa is especially sensitive to low temperatures. This is the most limiting factor for its distribution. During the coldest months, it can only withstand a few frosts of short duration and low intensity;

- On the Iberian Peninsula and the Balearic Islands, the months in which the lowest temperatures are reached are from December to February. For these months, the risk of frost according to Emberger criteria, and the number of frost days were studied:

$\circ$ Emberger criteria: if the average minimum temperature exceeds $7{ }^{\circ} \mathrm{C}$, the risk of light frost is low; if it is between 3 and $7{ }^{\circ} \mathrm{C}$ frosts are likely to happen. A subdivision with a value of $5{ }^{\circ} \mathrm{C}$ was made in order to define more precisely the possible areas of plant introduction. Average minimum temperatures below $3{ }^{\circ} \mathrm{C}$ mean that frosts are definitely going to occur, so this range is not considered for moringa cultivation.

To evaluate the risk of frost, we applied the Emberger criteria with the values of 3, 5 and $7{ }^{\circ} \mathrm{C}$ as the minimum average temperatures during the three winter months. Values lower than $3{ }^{\circ} \mathrm{C}$ mean that frost is very likely to occur; hence, these values were put aside.

Between 3 and $7{ }^{\circ} \mathrm{C}$, frosts are likely to happen. These areas are subdivided into two: above or below $5{ }^{\circ} \mathrm{C}$; areas with values above $5{ }^{\circ} \mathrm{C}$ are better suited for moringa. In frost-free areas, $>7^{\circ} \mathrm{C}$, the plant can thrive.

- The factor "number of days of frost" aims to ensure that the plant will not perish by persistent risk of frost. The higher the number of frost days, the higher the risk that these frosts will be persistent. Regions without frost, or with only sporadic frost (1 to 5 days), are the best. Areas with intermediate frost (from 6-20 days) present a risk. If more than 20 days of frost are registered, the zone is excluded.

- To discard areas with low temperatures, the maps with the Emberger criteria and the number of frost days were superimposed. 
- The average annual isotherm of $15^{\circ} \mathrm{C}$ marks the limit of life for moringa. Areas that do not exceed this value will be put aside.

- Growth of moringa occurs when the average monthly temperature reaches $20^{\circ} \mathrm{C}$. Areas with at least four months $\mathrm{T}>=20^{\circ} \mathrm{C}$ are selected. This ensures that the seed harvest cycle is completed or that at least three forage crops are obtained.

- Need for watering: from the literature we have collected, the common limiting values of precipitation for woodland persistence. These are: $300 \mathrm{~mm}$ (below this level trees cannot grow), $500 \mathrm{~mm}$ (below this limit, trees have some limitations; above it, there are no problems). The isohyet of $800 \mathrm{~mm}$ marks the limit of irrigation needs for forage (Broin, 2010) and above the isohyet of $1,500 \mathrm{~mm}$, the rain will damage flowers and will affect fruiting (Garavito, 2010). These values are not reached in the study area.

Based on these data we started to draw the maps as shown in the following section.

\section{RESULTS}

Only very few and very small zones reach an average temperature above $48{ }^{\circ} \mathrm{C}$. So, we considered that there is no limitation by high temperatures.

Figure 1.a) shows the areas, where the average annual temperature is above $15^{\circ} \mathrm{C}$, which means that the plant is expected to grow.

Figure 1.b) shows areas, where the number of months in which Tmed $\geq 20{ }^{\circ} \mathrm{C}$ is 4 or more, securing the minimum time required to reach pod harvest.
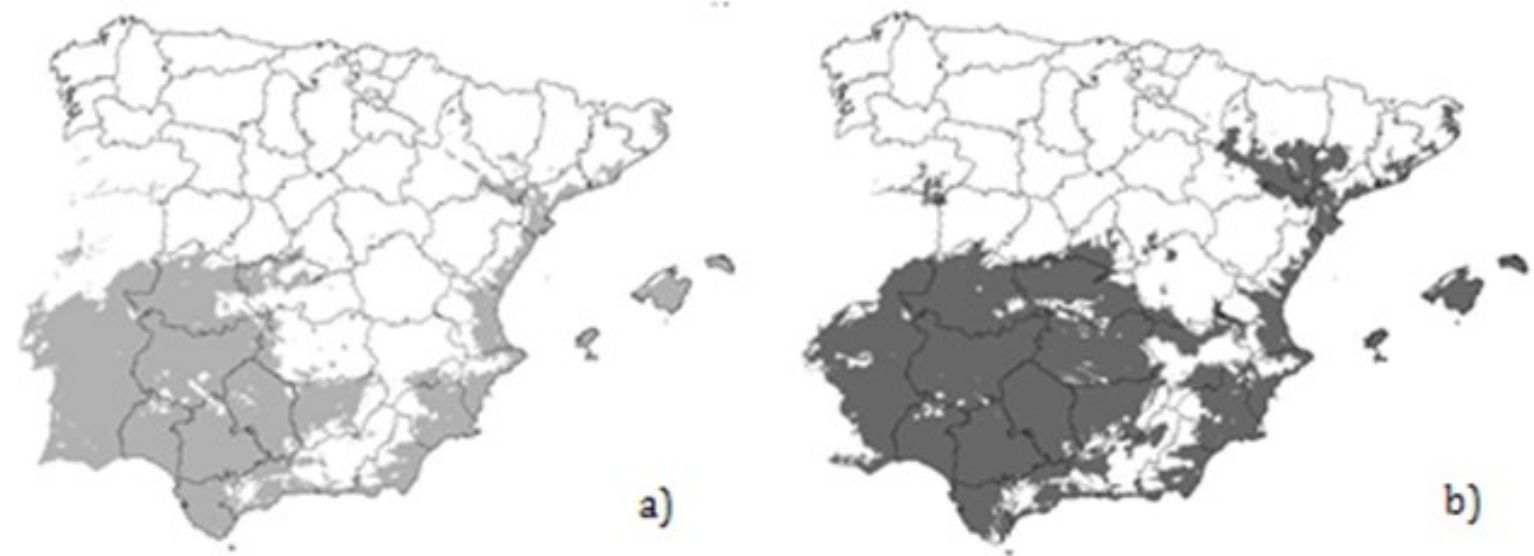

Figure 1. a) Annual isotherm $\mathrm{T}=15^{\circ} \mathrm{C}$. Figure 1.b) № of months that Tmed $\geq 20^{\circ} \mathrm{C}$ is 4 or more.
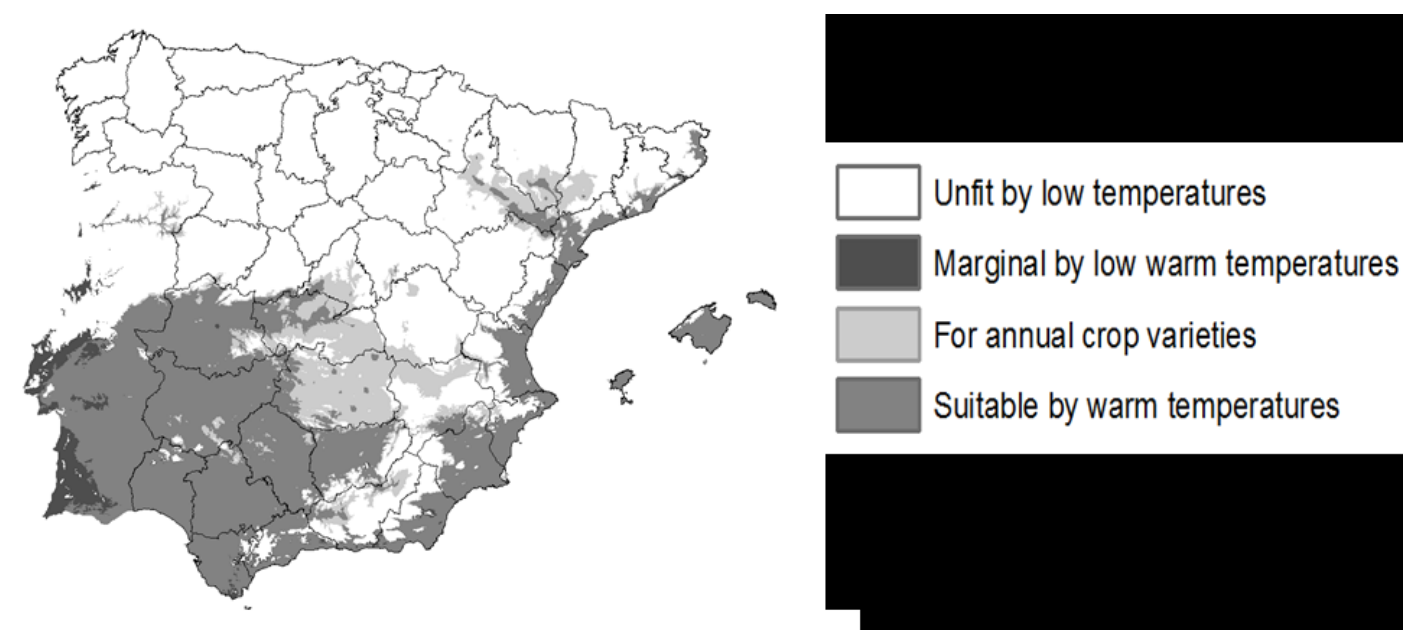

Figure 2: Potential growing areas for moringa with regard to temperature. 
Combining both figures, Figure 2 is obtained, which provides the potential growing areas for moringa with regard to heat.

Figure 3 is obtained by overlaying the maps of the Emberger criteria and the number of frost days. Figure 3 shows the possible growing areas depending on the duration and intensity of frost. Regions without frost or occasional frosts (1-5 days) are preferred. Areas with intermediate frost (6-20 days) are a risk, and more than 20 frost days, are considered excluded.

By combining Figures 2 and 3, Figure 4 is obtained. The latter classifies the potential growing areas of moringa based on the temperature conditions in two categories, annual and perennial, and these are ranging from marginal to optimal.

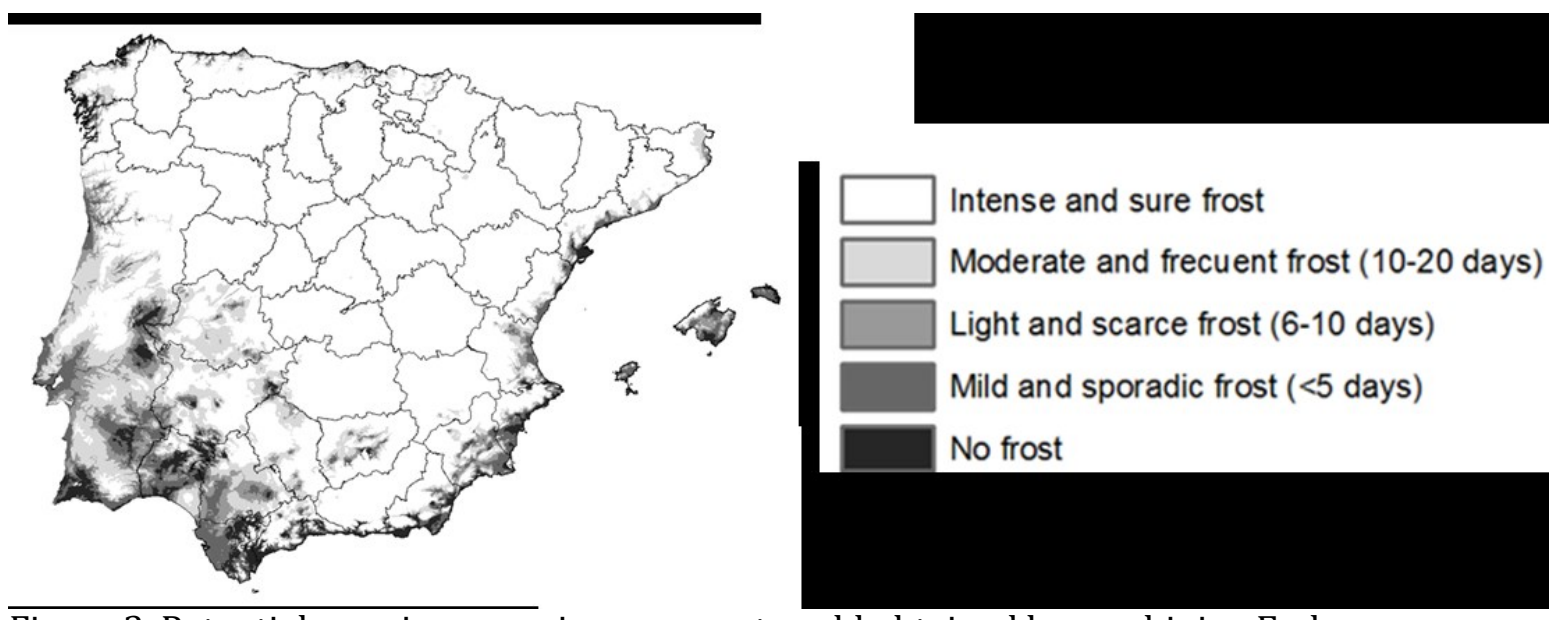

Figure 3. Potential growing areas in response to cold obtained by combining Emberger criteria and days of frost.

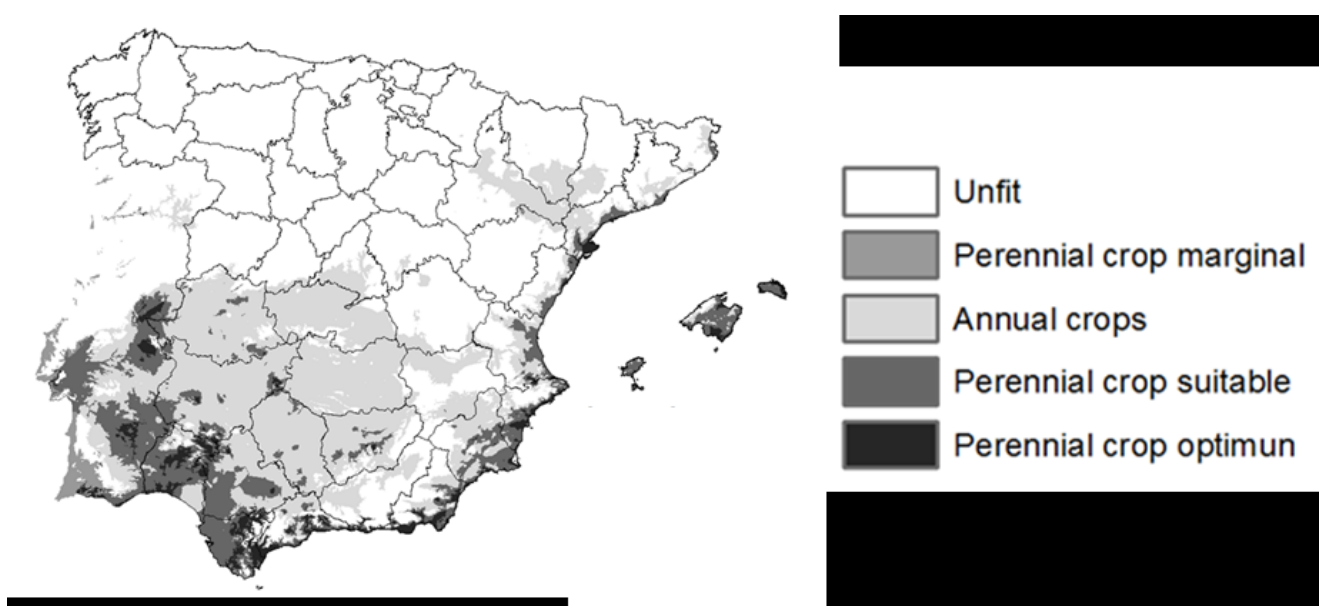

Figure 4. Classification of potential growing areas.

Figure 5.a) shows a map of rainfall for the crop ranges on the Iberian Peninsula that have been defined for moringa. Combining these ranges with the areas defined in Figure 4, Figure 5.b) is obtained. In this figure, the areas where irrigation is required are defined in Table 1, either for use of moringa as forage or for seed production. 

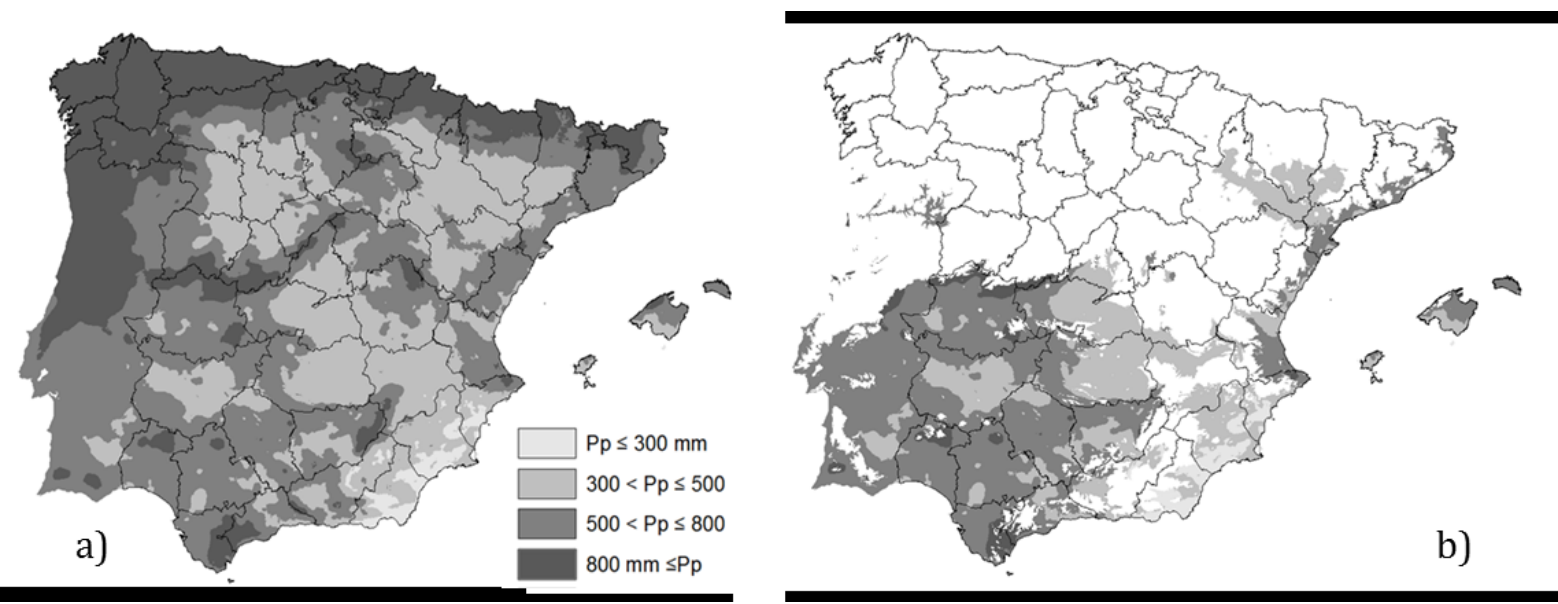

Figure 5. a) Isohyets on the Iberian Peninsula. b) Isohyets in the potential growing areas.

Table 1. Irrigation requirements for use of moringa as forage crop or for seed production.

\begin{tabular}{cccc}
\hline & Pp (mm) & Seeds & Forage \\
\hline & $\mathrm{Pp} \leq 300$ & Watering required & Watering required \\
$300<\mathrm{Pp} \leq 500$ & Watering recommended & Watering required \\
$500<\mathrm{Pp} \leq 800$ & No watering required & Watering required \\
$800<\mathrm{Pp}$ & No watering required & No watering required \\
\hline
\end{tabular}

\section{DISCUSSION}

We have been working with the help of data obtained from the "Climate Atlas of the Iberian Peninsula", covering the period 1971-2000. Due to the effect of global warming, during the past three decades the average temperature has been rising $0.5^{\circ} \mathrm{C}$ per decade (Pérez, 2010). This fact can modify the maps presented here leading to an increase of the areas, where it is possible to introduce the moringa tree.

The precipitation data used here were those derived from tropical or subtropical conditions. No information is available on the precipitation requirements of moringa under temperate climate conditions.

\section{CONCLUSIONS}

The potential growing area for Moringa oleifera on the Iberian Peninsula and Balearic Islands has been defined. Moringa can grow on more than $40 \%$ of this land area. Out of this $40 \%$ surface area, $70 \%$ would be suitable for growing moringa as annual crop and the rest, about $70,000 \mathrm{~km}^{2}$, would be suitable to grow permanent moringa crops, either as fodder or for seed production.

Moringa oleifera is a crop of great interest for introduction into the semi-arid regions of southern Andalusia and the Mediterranean coast, where the cultivation of this crop could increase the profitability of these lands. With the aim to produce leaves and pods for human consumption, some trials have been conducted in Almeria in greenhouses with good results.

Growing moringa as forage crop, it is necessary to consider irrigation as mandatory in all areas. Also if moringa is grown to produce seeds, irrigation will be necessary in almost all areas. Only in zones like the eastern half of the province of Cadiz, moringa could grow without irrigation.

\section{ACKNOWLEDGEMENTS}

We would like to acknowledge AEMET for providing us the Iberian Climate Atlas data. Without this information, it would not have been possible to undertake this research work. 


\section{Literature cited}

AEMET (Agencia Estatal de Meteorología). (2011). Atlas climático ibérico. Ed. Ministerio de Medio Ambiente y Medio Rural y Marino, 79 p. España ISBN: 978-84-7837-079-5.

Bertoni, M.S. (1927). Agenda y Mentor Agrícola. Guía del agricultor y colono. 4ạ edición. Ed. Ex sylvis. Puerto Bertoni. Alto Paraná. Paraguay. 512 p. http://www.mag.gov.py/bina/dato/agenda_y_mentor_agricola.pdf.

Broin, M.; de Saint Sauveur, A. (2010). Growing and processing moringa leaves. Moringanews / Moringa Association of Ghana. Gémenos, France. http://miracletrees.org/moringadoc/moringa_book_growing_and_processing_moringa_leaves.pdf.

Falasca, S.; Bernabé, M.A. (2008). Potenciales usos y delimitación del área de cultivo de Moringa oleifera en Argentina. Redesma. http://revistavirtual.redesma.org/vol3/pdf/investigacion/Moringa.pdf (Last visit: 01-132014).

Garavito, U. (2008). Moringa oleifera, alimento ecológico para ganado vacuno, porcino, equino, aves y peces, para alimentación humana, también para producción de etanol y biodiesel. Colombia. http://www.engormix.com/MA-agricultura/cultivos-tropicales/foros/articulo-moringa-oleifera-alimentot13131/078-p0.htm.

García Roa, M. (2003). Producción de semillas forestales de especies forrajeras enfatizados en sistemas silvopastoriles. Instituto Nacional $\quad$ Forestal $\quad$ (INAFOR). Nicaragua. $\quad$ (37). http://www.inafor.gob.ni/publica/doc_download/22-produccion-de-semillas-forestales-especiesforajeras.html.

Gómez Ortega, C. (1796). Elenchus Plantarum Horti Regii Botanici Matritensis. Anno MDCCXCVI. http://bibdigital.rjb.csic.es/ing/Libro.php?Libro=3731.

Janh, S.A.A; Musnad, H.A.; Burgstaller, H. (1986). The tree that purifies water: Cultivating multipurpose Moringaceae in the Sudan. Unasylva, 38(152):23-29. http://www.fao.org/docrep/r7750E/r7750e04.htm.

Khuroo, A.A.; Weber, E.; Malik, A.H.; Reshi, Z.A.; Dar G.H. (2011). Altitudinal distribution patterns of the native and alien woody flora in Kashmir Himalaya, India. Environ Res. 2011 Oct; 111(7):967-77. doi: 10.1016/j.envres.2011.05.006. Epub 2011 Jul 23.

Muhl, Q. E., du Toit, E. S., \& Robbertse, P. J. (2011). Temperature effect on seed germination and seedling growth of Moringa oleifera Lam. Seed Science and Technology, 39(1), 208-213. doi:10.15258/sst.2011.39.1.19.

NRC (National Research Council). (2006). Lost crops of Africa. Volume II: vegetables. The National Academies Press. 246-267. http://www.nap.edu/read/11763/chapter/16\#266.

OCHA (UN Office for the Coordination of Humanitarian Affairs). (2015). Asia-Pacific: Köppen-Geiger Climate Classification http://reliefweb.int/map/world/asia-pacific-k-ppen-geiger-climate-classification-jul-2015.

Pacheco, R.M. (2006). Análisis del intercambio de plantas entre México y Asia de los siglos XVI al XIX. Master's Thesis. 274 p. UNAM. México. http://132.248.9.195/pd2007/0612197/Index.html.

Parrota, J.A. (2000). Capítulo Moringa oleifera, pag. 366-370. Bioecología de Arbóreas Nativos y Exóticos de Puerto Rico y las Indias Occidentales. Gen. Tech. Rep. IITF-15. Río Piedras, Puerto Rico: Departamento de Agricultura de los Estados Unidos, Servicio Forestal, Instituto Internacional de Dasonomía Tropical. 582 p. Francis, John K.; Lowe, Carol A., eds. Trabanino, Salvador, traductor. http://data.fs.usda.gov/research/pubs/iitf/Bioecologia_gtr15.pdf. 
Pérez, F.F.; Boscolo, R.E. (eds) (2010). Clima en España: pasado, presente y futuro. Informe de Evaluación del Cambio Climático Regional. (Madrid). CLIVAR : Ministerio de Medio Ambiente y Medio Rural y Marino: Ministerio de Ciencia e Innovación. 83 p. http://hdl.handle.net/10261/23600.

Prabhakar M, Hebbar SS (2008). Annual drumstick (Moringa oleifera Lam.). In: Peter KV (ed) Underutilized and underexploited horticultural crops, vol 4. New India Publishing Agency, New Delhi, pp 111-130. https://books.google.es/books?isbn=8189422901.

Radovich, T. (2011). Farm and Forestry Production and Marketing Profile for Moringa (Moringa oleifera). In: Elevitch, C.R. (ed.). Specialty Crops for Pacific Island Agroforestry. Permanent Agriculture Resources (PAR), Holualoa, Hawaii. http:// agroforestry.net/scps.

Roloff, A.; Weisgerber, H.; Lang U.; Stimm B. (2009). Enzyklopädie der Holzgewächse, Handbuch und Atlas der Dendrologie. WILEY-VCH Verlag GmbH \& Co. KGaA, Weinheim. ISBN: 978-3-527-32141-4.

Sánchez de Lorenzo-Cáceres, J.M. (2004). Las plantas ornamentales y sus zonas de rusticidad en España. http://www.arbolesornamentales.es/PLANTAS\%20Y\%20ZONAS\%20DE\%20RUSTICIDAD.pdf.

Sánchez, N.R. (2004). Marango: cultivo y utilización en la alimentación animal. Guía técnica no 5 . Universidad Nacional Agraria. Nicaragua. http://repositorio.una.edu.ni/id/eprint/2410

Sánchez, N.R., Ledin, S. \& Ledin, I. (2006) Biomass production and chemical composition of Moringa oleifera under different management regimes in Nicaragua. Agroforest Syst 66: 231-242. doi:10.1007/s10457-005$8847-y$.

Sutherland, J.P.; Folkard; G.K. \& Grant; W.D. (1989). Seeds of Moringa species as naturally occurring flocculants for water treatment. Science, Technology \& Development, 1989, 7(3), 191-197. 